\title{
Koroška 8000: digit responses to cold stress following himalayan expedition to broadpeak, Pakistan $(8051 \mathrm{~m})$
}

\author{
Jurij Gorjanc ${ }^{1 *}$, Shawnda A Morrison², Adam C McDonnell ${ }^{3,4}$, Jan Babič ${ }^{3}$, Igor B Mekjavic ${ }^{3}$ \\ From 15th International Conference on Environmental Ergonomics (ICEE XV) \\ Portsmouth, UK. 28 June - 3 July 2015
}

\begin{abstract}
Introduction
We investigated the effects chronic hypobaric hypoxia exposure would have on alpinists' physiological adaptations, including: aerobic fitness, body composition, haematological variables and digit perfusion responses to cold stress, performed before and immediately after a 35 day high altitude climbing expedition.
\end{abstract}

\section{Methods}

Seven elite Slovenian alpinists completed a battery of physiological tests, including a cold stress test protocol previously used to determine changes in digit temperatures [1-3]. Briefly, alpinists immersed their hand or foot (random order) into a circulated, warm water bath $\left(35^{\circ} \mathrm{C}\right)$ for 5 min to standardise skin temperature, and then in a cold water bath $\left(8^{\circ} \mathrm{C}\right)$ for $30 \mathrm{~min}$. Individual digit temperatures (thermocouples) were measured continuously for each min during the protocol, and for an additional $10 \mathrm{~min}$ of passive recovery in air.

\section{Results}

5/7 alpinists successfully summited Broadpeak (8051 m elevation). Of those alpinists, 4/5 demonstrated higher cold-induced vasodilation (CIVD) wave amplitudes in mean finger temperatures, or higher recovery temperatures, (or both), post-expedition. In the feet, $1 / 5$ had higher wave amplitudes, $1 / 5$ had higher passive recovery temperatures, whereas $2 / 5$ had lower mean toe temperatures during cold exposure, and one had no discernible alterations post-expedition. One alpinist declined participation in the cold stress testing in this expedition because he had

\footnotetext{
* Correspondence: jurij.gorjanc@mf.uni-lj.si

'Department of Surgery, Hospital of the Brothers of St. John of God,

Spitalgasse 26, A-9300 Sankt Veit an der Glan, Austria

Full list of author information is available at the end of the article
}

previously completed an identical protocol and reported extreme discomfort in his digits during the cold water immersion phase of testing. Area under the curve calculations for the hands found 5/5 alpinists had higher values post-expedition, whilst in the toes, $3 / 5$ had higher values compared to pre-expedition.

\section{Discussion}

Previous results have demonstrated a significant enhancement of the CIVD response in both fingers and toes of alpinists returning from high altitude expeditions 1 , and following 15-months of military training in the cold, 4, whilst others have reported variable differences following repeated cold exposure, depending on altitude 5,. Vasodilatation and vasoconstriction responses are non-generalisable between hands and feet 3 . It is not clear whether uniform peripheral cold adaptation per se occurs in both hands and feet following combined exposure to high altitude and cold in this particular population.

\section{Conclusion}

Alpinists presented vastly different digit responses to cold stress after exposure to hypobaric hypoxia.

\section{Authors' details \\ 'Department of Surgery, Hospital of the Brothers of St. John of God, \\ Spitalgasse 26, A-9300 Sankt Veit an der Glan, Austria. ${ }^{2}$ Science and Research Centre, University of Primorska, Garibaldijeva 1, Koper, Slovenia. ${ }^{3}$ Department of Automation, Biocybernetics and Robotics, Jožef Stefan Institute, Jamova 39, SI-1000 Ljubljana, Slovenia. ${ }^{4} J$ ozef Stefan International Postgraduate School, Jamova Cesta 39, 1000 Ljubljana, Slovenia.}

\section{Published: 14 September 2015}




\section{References}

1. Felicijan A, Goja P, Milčinski M, Cheung SS, Mekjavic IB: Enhancement of cold-induced vasodilatation following acclimatization to altitude. Eur J Appl Physiol 2008, 104(2):201-206.

2. Amon M, Keramidas ME, Kounalakis SN, Mekjavic IB: The Effect of a Sleep High-Train Low Regimen on the Finger Cold-Induced Vasodilation Response. High Alt Med Biol 2012, 13(1):32-39.

3. Cheung SS, Mekjavic IB: Cold-induced vasodilatation is not homogenous or generalizable across the hand and feet. Eur J Appl Physiol. 2007 99(6):701-705.

4. Brandstrom H, Grip H, Hallberg P, Gronlund C, Angquist K-A, Giesbrecht GG: Hand cold recovery responses before and after 15 months of military trainig in a cold climate. Aviat Space Envir MD 2008, 79(9):904-908.

5. Daanen $\mathrm{H}$, van Ruiten $\mathrm{H}$ : Cold-induced peripheral vasodilation at high altitude- a field study. High Alt Med Biol 2000, 1(4):323-329.

\section{doi:10.1186/2046-7648-4-S1-A43}

Cite this article as: Gorjanc et al:: Koroška 8000: digit responses to cold stress following himalayan expedition to broadpeak, Pakistan (8051 m). Extreme Physiology \& Medicine 2015 4(Suppl 1):A43.

\section{Submit your next manuscript to BioMed Central and take full advantage of:}

- Convenient online submission

- Thorough peer review

- No space constraints or color figure charges

- Immediate publication on acceptance

- Inclusion in PubMed, CAS, Scopus and Google Scholar

- Research which is freely available for redistribution

Submit your manuscript at www.biomedcentral.com/submit 